\title{
Biopsychosocial Determinants of Pregnant Women's Behaviour in Conducting Human Immunodeficiency Virus/ Acquired Immunodeficiency Syndrome (HIV/AIDS) Tests in Madiun
}

\author{
Wida Rahma Arwiyantasari'), Supriyadi Hari Respati²), \\ Eti Poncorini Pamungkasari3)
}

1) Muhammadiyah Midwifery Academy, Madiun

2) Department of Obstetrics and Gynecology, RSUD Dr. Moewardi, Surakarta

3) Faculty of Medicine, Sebelas Maret University, Surakarta

\begin{abstract}
Background: Human Immunodeficiency Virus (HIV) is top ranked infectious disease which causes death with high mortality and morbidity rates, and requires diagnosis and long-term therapy (WHO, 2013). In October 2016, Health Office of Madiun City stated that in 2015, there were 2,772 pregnant women, among those only 1,120 conducted HIV-AIDS tests and 4 of them declared HIV positive. These numbers indicated that the participations of pregnant women in conducting HIV-AIDS tests are not optimal. This study aimed to discover biopsychosocial determinants in conducting HIV-AIDS tests on pregnant women in Madiun.

Subjects and Method: This was an analytic observational study with case control design. A total of 108 samples of pregnant women in Madiun which consisted of 54 pregnant women who conducted HIV/AIDS tests as cases, and 54 pregnant women who did not conduct HIV/ AIDS tests as controls were collected by using fixed disease sampling The device to gather the data was a set of questionnaire. Data analysis used Chi Square and path analysis.

Results: There were positive influence of family support $(b=1.57 ; 95 \% \mathrm{CI}=0.52$ to $2.63 ; \mathrm{p}=0.004)$, information exposure $(b=1.14 ; 95 \% \mathrm{CI}=0.33$ to $1.95 ; \mathrm{p}=0.006)$, perceived seriousness $(\mathrm{b}=1.21 ; 95 \%$ $\mathrm{CI}=0.14$ to $2.28 ; \mathrm{p}=0.027$ ), perceived vulnerability $\mathrm{b}=1.12 ; 95 \% \mathrm{CI}=0.12$ to $2.13 ; \mathrm{p}=0.028$ ), perceived benefit $(\mathrm{b}=1.28 ; 95 \% \mathrm{CI}=0.23$ to $2.31 ; \mathrm{p}=0.017)$ on pregnant women's behaviour in conducting HIV/ AIDS tests, and statistically significant. There were negative influence of family income $(b=-0.73 ; 95 \% \mathrm{CI}=-1.51$ to $0.05 ; \mathrm{p}=0.067)$, perceived obstacles $(\mathrm{b}=-0.92 ; 95 \% \mathrm{CI}=-1.99$ to $0.15 ; \mathrm{p}=0.093)$ and statistically significant.

Conclusion: Family support, information exposure, family income, perceived seriousness, perceived vulnerability, perceived obstacles, and perceived benefit influence pregnant women in conducting HIV/ AIDS tests.
\end{abstract}

Keywords: determinants, bipsychosocial, HIV/ AIDS test

Correspondence: Wida Rahma Arwiyantasari. Muhammadiyah Midwifery Academy Madiun. Email: widarahmaarwiyantasari@ymail.com. Mobile: 085736709597.

\section{BACKGROUND}

Human Immunodeficiency Virus (HIV) is the top ranked infectious disease that cause death with high mortality and morbidity rates, and it requires diagnosis and longterm therapy (WHO, 2013). HIV is a virus that attacks white blood cells (leucocytes) inside a body that causes the decrease of the body's immune system which leads to
Acquired Immunodeficiency Syndrome (AIDS).

Since being reported for the first time in 1981 in United States of America, HIV/ AIDS has spread around the world including Indonesia where it is spreading very rapidly. The disease is responsible for the deaths of 25 millions people and has infected more than 40 million others. Based on a global report, in 2014, number of HIV pa- 
tients had been increasing which was 36 millions people and 1.2 millions died because of AIDS (UNAIDS, 2015). Indonesia is one of the countries in Asia that has been susceptible to Human Immunodeficiency Virus (HIV) as the consequence of economic and social life changes. HIV transmission generally happens as the consequence of human behaviour, thus put any individuals susceptible to the infection. Indonesia has become $5^{\text {th }}$ most-at-risk country in Asia for HIV-AIDS. HIV infection has been one of the contagious diseases that is grouped as the factor which influences maternal and infants mortality rates (Kemenkes, 2011).

HIV epidemic has entered a new chapter as HIV has infected a lot more numbers of women. 50\% of which are women and 2.1 millions children under 15 years old. In South and Southeast Asia, there are approximately 4 millions people infected HIV and AIDS. According to the WHO Progress Report of HIV-AIDS in SEATO Region (2011), there were approximately 1.3 millions (37\%) women were infected with HIV. The numbers of women infected with HIV are increasing every year so as the increasing number of men exercising sexual intercourse without any protections, thus infected their sexual partners.

Based on the data from December 2014, the number of cases on AIDS which was reported was 12,630 people and 26,433 people were infected with HIV. Among those number, 3,058 (24.2\%) people died. That number was much smaller than the number in reality, and based on the estimation so far as 2012, the number of people infected HIV/ AIDS in East Java had been approximately 57,321. Since September 2003, HIV-AIDS cases have been discovered in Madiun. In 2015, there were 26 cases in 3 different subdistricts. Cumulative cases number which had been found until the end of December 2016 were 212 (18.24\%) whereas the existing case estimation was 1,162 cases. These numbers indicate that there are 950 cases $(81.76 \%)$ still hidden. By revealing HIV/AIDS cases earlier, transmissive disease prevention and medications can be well executed (Public Health Office Madiun, 2016)

There are a lot of studies about HIVAIDS conducted previously. One of them is a study by Towsen and his colleagues from University College London Institute of Child Health (2008). They analysed 5,151 pregnancies among women who were HIV positive in England and Irish between 2000 and 2006. The results of this study indicated that thelevel of Mother to Child Transmision (MTCT) decreased from 20\% to 1.2\% in mid 1990. According to the researchers, the main reason of this decreasing number of MTCT level was the increasing number of women conducting HIV tests before pregnancies after the routine screening policy had been implemented in those countries. Routine screening improves the diagnosis level before labour. MTCT level was approximately $70 \%$ in 2000 . Then, it was approximately $95 \%$ in 2005 . That was the reason why in 1999 the routine screening policy was implemented in Irish, and between 2000 and 2003 it was implemented in England (Towsend, 2008). A study conducted by Mulyanti (2014) on contributing factors to pregnant women's behaviour in conducting HIV tests in Pontianak indicated that $7 \%$ of pregnant women conducted HIV tests and the most dominant factor was the source of information on HIV-AIDS. Pregnant women who had gotten the most information had the possibilities of 12,03 times more chances to conduct the HIV tests. Wulansari (2014) analysed the factors that correlated with pregnant women's intentions to make use of Voluntary Counseling and Testing (VCT) Services in Tangerang. 
Journal of Health Promotion and Behavior (2017), 2(2): 112-123

https://doi.org/10.26911/thejhpb.2017.02.02.02

The results indicated that $50 \%$ of pregnant women had the intentions to make use of VCT services. She also found that the variables of knowledge, behaviour, subjective norms and perceived behavioural control had significantly correlated with pregnant women's intentions to make use of VCT services.

Biopsychosocial model suggests that it is one's mental state behind any contributions to health or one's own disease manifestation. Whereas social aspects of biopsychosocial model refer to the influences of social-cultural-economic-political environments which surround the individual. Social aspects analyse diseases from sociological point of view and learn how far these external factors influence a patient's disease manifestations (Murti, 2016).

Based on a preliminary study in October 2016 at Public Health Office in Madiun, the results indicated that in 2015 there were 2,772 pregnant women, only 1,120 of them conducted HIV-AIDS tests and 4 of them were declared HIV positive. This number showed that pregnant women's participations in conducting HIV-AIDS tests were not optimal. Some factors that cause pregnant women do not do HIV tests earlier are the lack of information, abilities to afford the costs, and family support, and some women do not realise that their sexual partners are at risk to HIV-AIDS transmissions. Besides those factors, there are these influencial factors of the women's behaviour. Those are the self awareness to change her own behaviour in order to avoid getting infected or to minimise health risks, and the impulse within her own environment to change her behaviour, and this behaviour is based on Health Belief Model. This study aims to cognise if the factor of pregnant women's behaviour influences them in conducting HIV-AIDS tests.

\section{SUBJECTS AND METHOD \\ 1. Research Design \\ This study implemented analytic observa-} tional study design by using the approach of case control study. The factors to be examined were family support, family income, and access to information, and perceived vulnerability, perceived seriousness, obstacles and benefits which were felt by pregnant women, and their influences would be seen through the behaviour of pregnant women in conducting HIV/AIDS tests in Madiun. The data was collected using a set of questionnaire completed by the subjects of this study. Time period in conducting this study was from February to March 2017.

\section{Population and Sample}

Population of this study was the entire pregnant women in their first, second and third trimester within the region of Madiun. Between February and March 2017, there was a total of 205 subjects of this study. The total samples (n) in this study was $\mathrm{n}=\left(15^{-}\right.$ 20) samples for each independent variable (Murti, 2013). Because there were 7 independent variables, thus $\mathrm{n}=7 \times \mathrm{n}(15-20=$ (105 samples-140 samples). Sampling technique used in the study was Fixed disease sampling which wis selecting the samples based on the disease status, whereas exposure status is varied based on the "fixed" disease status (Murti, 2013). This technique non randomly selects the sample. To increase the strength of this study, there was a ratio of 1:1 for case and control. There were 54 subjects for cases and 54 subjects for controls.

\section{Research Variables}

The dependent variable of this study was the numbers of visits in conducting HIVAIDS tests. The independent variables were family support, information exposure, family income, perceived seriousness, per- 
ceived vulnerability, perceived benefit, and perceptions of obtacles.

\section{Data Analysis}

The data used in this study were primary data which were obtained from structured interview with the entire pregnant women in their first, second and third trimester. These data were gathered by the researchers with the help from one midwifery to accompany the subjects. Instrument used in this study was a set of quetionnaire which was read by the researchers directly to those pregnant women in their first, second and third semester.

The data were collected after the researchers explained briefly about their intentions and purposes on the interviews, then they asked for the subjects' informed consents. Then, the researchers started the interviews based on the set of questionnaire they had prepared previously.

The data were collected after conducting the validity and reliability tests. The set of questionnaire was presented to pregnant women in their first, second and third trimester who had the same characteristics as the pregnant women in their first, second and third trimester who had conducted HIV/ AIDS tests. To analyse the data, this study implemented bivariate analysis using SPSS version 22, and multivariate analysis using Stata 13 path analysis.

\section{Reliability}

The reliability of this study was based on alpha cronbach analysis. A variable is declared reliable only if the value of alpha cronbach >0.6. The higher the alpha cronbach is, the more consistent the measurement device is. However, there are some conditions whereby the value of the alpha cronbach is high but does not indicate a good measurement device. The value of alpha cronbach depends on how large the correlations between items and total items in a measurement device. If the total number of question items is plenty, the alpha cronbach will increase although this does not mean that this is a good measurement device (Murti, 2016).

\begin{tabular}{|c|c|c|}
\hline Variable & $\begin{array}{c}\text { Corrected } \\
\text { Item-Total } \\
\text { Corelation }\end{array}$ & $\begin{array}{c}\text { Alpha } \\
\text { Cronbach }\end{array}$ \\
\hline $\begin{array}{l}\text { Perceived } \\
\text { vulnerability }\end{array}$ & $\geq 0.39$ & 0.74 \\
\hline $\begin{array}{l}\text { Perceived } \\
\text { seriousness }\end{array}$ & $\geq 0.63$ & 0.77 \\
\hline $\begin{array}{l}\text { Perceived } \\
\text { benefit }\end{array}$ & $\geq 0.37$ & 0.76 \\
\hline $\begin{array}{l}\text { Perceived } \\
\text { obstacles }\end{array}$ & $\geq 0.81$ & 0.87 \\
\hline
\end{tabular}

Reliability test results on perceptions of individual vulnerability, perceptions of the seriousness of the disease, perceived benefit and perceived obstacles indicated that the item total correlation $\geq 0.20$ for each of the question items, and Alpha Cronbach $\geq 0.60$. Thus, the set of questionnaire was used to obtain any data in this study.

In this study, the measurement device used by the researchers to measure the value of the variables was a set of questionnaire. It consisted of some questions to be asked to measure the influence of dependent variables on the independent variables. There were seven variables in this study. Those were family support, source of information, family income, perceived seriousness, perceived vulnerability, perceived obstacles and perceived benefit. The measurement of perceptions of behaviour was based on the respondents' answers which were either Strongly Agree (SA), Agree (A), Disagree (D) and Strongly Disagree (SD) to questions in the set of questionnaire. 
Journal of Health Promotion and Behavior (2017), 2(2): 112-123

https://doi.org/10.26911/thejhpb.2017.02.02.02

\section{RESULTS}

\section{Characteristics of the Subjects of this Study}

The characteristics results of the subjects of this study in Table 2 indicated that the majority of the subjects in case and in control had the levels of education of Senior High School graduates that were 32 women ( 59 . $3 \%)$. The subjects of this study who had jobs as enterpreneurs were 21 women (38.9\%) in case and 25 women (46.3\%) in control. The jobs of these women's husbands were enterpreneurs which were 37 men (68.5\%) in case and 33 men $(61.1 \%)$ in control. Whereas the variable of those who had family income $\geq$ Rp. 1,509,005.00 in case were 34 subjects (63\%), and those who had family income <Rp. 1,509,005.00 in control were 37 subjects (68.5\%).

\section{Bivariate Analysis}

The influence of family support, family income, information exposure, perceived seriousness, perceived obstacles, perceptions of vunerability and perceived benefit in conducting HIV/ AIDS test was figured in Table 3 .

Table 2. Characteristics of the subjects of this study in case and control

\begin{tabular}{|c|c|c|c|c|c|}
\hline \multirow[t]{2}{*}{ Characteristics } & \multirow[t]{2}{*}{ Criteria } & \multicolumn{2}{|c|}{ Case } & \multicolumn{2}{|c|}{ Control } \\
\hline & & $\mathrm{n}$ & $\%$ & $\mathrm{n}$ & $\%$ \\
\hline \multirow{4}{*}{$\begin{array}{l}\text { Maternal Levels of } \\
\text { Education }\end{array}$} & Primary School & 1 & 1.9 & 2 & 3.7 \\
\hline & Junior High School & 7 & 13.0 & 9 & 16.7 \\
\hline & Senior High School & 32 & 59.3 & 32 & $59 \cdot 3$ \\
\hline & Undergraduate & 14 & 25.9 & 11 & 20.4 \\
\hline \multirow[t]{5}{*}{ Maternal Job Status } & Unemployed & 13 & 24,1 & 9 & 16.7 \\
\hline & Civil Servant & 2 & 3.7 & 7 & 13.0 \\
\hline & Enterpreneur & 21 & 38.9 & 25 & 46.3 \\
\hline & Labour & 5 & 9.3 & 5 & 9.3 \\
\hline & Others & 13 & 24.1 & 8 & 14.8 \\
\hline \multirow[t]{6}{*}{ Paternal Job Status } & Unemployed & $\mathrm{O}$ & 0 & 1 & 1.9 \\
\hline & Civil Servant & 4 & $7 \cdot 4$ & 7 & 13.0 \\
\hline & Soldier/Police Officer & 3 & 5.6 & 8 & 14.8 \\
\hline & Enterpreneur & 37 & 68.5 & 33 & 61.1 \\
\hline & Labour & 3 & 5.6 & 4 & $7 \cdot 4$ \\
\hline & Chauffeur & 5 & $9 \cdot 3$ & 1 & 1.9 \\
\hline \multirow[t]{2}{*}{ Family Income } & $<$ Rp. $1,509,005.00$ & 20 & 37 & 37 & 68.5 \\
\hline & $\geq 1,509,005.00$ & 34 & 63 & 17 & 31.5 \\
\hline
\end{tabular}

The variable of family support indicated that the value of its Odds Ratio was 6.21 which meant that the pregnant women who had gotten strong family support had 6.21 times more possibilities to do the HIV/AIDS tests than those who had gotten weak/low family support. The result of the analysis indicated that there was an influence of family support to the conduct of HIV/AIDS tests, and was statistically significant $(\mathrm{OR}=6.21 ; 95 \% \mathrm{CI}=2.70$ to 14.35; $\mathrm{p}<0.001)$.

The variable of family income indicated the value of Odds Ratio was 3.70 which meant that the pregnant women who had family income $\geq$ Rp. 1.509.005,00 had 3.70 more possibilities to do the HIV/AIDS tests than those who had family income < Rp. 1.509.005,00. This analysis result indicated that there was an influence of family income to the conduct of HIV/AIDS tests, and was statistically very significant $(\mathrm{OR}=$ $3.70 ; 95 \% \mathrm{CI}=1.67$ to $8.21 ; \mathrm{p}=0.001$ ).

The variable of infomation exposure indicated that the value of Odds Ratio 6.78 which meant that pregnant women who had exposed to the information about HIV/ AIDS had 6.78 more possibilities to do HIV/ AIDS tests than those who had not. This result analysis indicated that there was 
an influence of information exposure on the conduct of HIV/ AIDS tests, and was statis- tically very significant $(\mathrm{OR}=6.78 ; 95 \% \mathrm{CI}=$ 2.92 to $15.77 ; \mathrm{p}<0.001)$.

Table 3. Bivariate analysis of the influence of family support, family income, information exposure, perceived seriousness, perceived vulnerability, perceived obstacles and perceived benefits in conducting HIV/AIDS test

\begin{tabular}{|c|c|c|c|c|c|c|}
\hline \multirow[t]{3}{*}{ Variable } & \multicolumn{4}{|c|}{$\begin{array}{c}\text { The Conduct of HIV/AIDS } \\
\text { Test }\end{array}$} & \multirow{3}{*}{$\begin{array}{c}\text { OR } \\
(95 \% \mathrm{CI})\end{array}$} & \multirow{3}{*}{$\mathrm{p}$} \\
\hline & \multicolumn{2}{|c|}{$\begin{array}{c}\text { Case } \\
(\mathrm{n}=54)\end{array}$} & \multicolumn{2}{|c|}{$\begin{array}{l}\text { Control } \\
(\mathrm{n}=54)\end{array}$} & & \\
\hline & $\mathrm{n}$ & $\%$ & $\mathrm{n}$ & $\%$ & & \\
\hline \multicolumn{7}{|l|}{ Family Support } \\
\hline Strong & 37 & 72.5 & 14 & 27.5 & \multirow{3}{*}{$\begin{array}{c}6.21 \\
(2.70-14 \cdot 35)\end{array}$} & \multirow{2}{*}{$<0.001$} \\
\hline Weak & 17 & 29.8 & 40 & 70.2 & & \\
\hline Family Income & & & & & & \\
\hline < Rp. 1509. 005,00 & 20 & 35.1 & 37 & 64.9 & \multirow{2}{*}{$\begin{array}{c}3.70 \\
(1.67-8.21)\end{array}$} & \multirow[b]{2}{*}{0.001} \\
\hline $\begin{array}{l}\geq \mathrm{Rp} .1509 .005,00 \\
\text { Information Exposure }\end{array}$ & 34 & 66.7 & 17 & $33 \cdot 3$ & & \\
\hline High & 40 & 71.4 & 16 & 28.6 & \multirow{2}{*}{$\begin{array}{c}6.78 \\
(2.92-15.77)\end{array}$} & \multirow{2}{*}{$<0.001$} \\
\hline $\begin{array}{l}\text { Low } \\
\text { Perceived seriousness }\end{array}$ & 14 & 26.9 & 38 & 73.1 & & \\
\hline High & 34 & $77 \cdot 3$ & 10 & 22.7 & \multirow{2}{*}{$\begin{array}{c}7.48 \\
(3.10-18.05)\end{array}$} & \multirow{2}{*}{$<0.001$} \\
\hline $\begin{array}{l}\text { Low } \\
\text { Perceived obstacles }\end{array}$ & 20 & 31.3 & 44 & 68.6 & & \\
\hline Big & 11 & 23.9 & 35 & 76.1 & \multirow{2}{*}{$\begin{array}{c}0.14 \\
(0.06-0.33)\end{array}$} & \multirow{2}{*}{$<0.001$} \\
\hline $\begin{array}{l}\text { Small } \\
\text { Perceived vulnerability }\end{array}$ & 43 & 69.4 & 19 & 30.6 & & \\
\hline High & 38 & 67.9 & 18 & 32.1 & \multirow{2}{*}{$\begin{array}{c}4.75 \\
(2.17-10.71)\end{array}$} & \multirow{2}{*}{$<0.001$} \\
\hline $\begin{array}{l}\text { Low } \\
\text { Perceived benefits }\end{array}$ & 16 & 30.8 & 36 & 69.2 & & \\
\hline $\begin{array}{l}\text { Low } \\
\text { High }\end{array}$ & $\begin{array}{l}35 \\
19\end{array}$ & $\begin{array}{l}68.6 \\
33 \cdot 3\end{array}$ & $\begin{array}{l}16 \\
38\end{array}$ & $\begin{array}{l}31.4 \\
66.7\end{array}$ & $\begin{array}{c}4.37 \\
(1.95-9.82)\end{array}$ & $<0.001$ \\
\hline
\end{tabular}

The variable of Perceived seriousness ceptions of obtacles had $1 / 4$ times more had the value of Odds Ratio 7.48 which meant that pregnant women with high perceptions of disease seriousness had 7.48 times more possibilities to do the HIV/ AIDS tests than those with low perceptions of disease seriousness. This analysis result indicated that there was an influence of perceived seriousness on the conduct of HIV/ AIDS tests and was statistically very significant $(\mathrm{OR}=7.48 ; 95 \% \quad \mathrm{CI}=3.10$ to 18.05; $\mathrm{p}<0.001)$.

The variable of perceived obstacles had the value of Odds Ratio 0.14 which meant that pregnant women with low perpossibilities in conducting HIV/ AIDS tests than those with high perceived obstacles. This analysis result indicated that there was an influence of perceived obstacles on the conduct of HIV/ AIDS tests and was statistically very significant $(\mathrm{OR}=0.14 ; 95 \% \mathrm{CI}=$ 0.06 to $0.33 ; \mathrm{p}<0.001)$.

The variable of perceived vulnerability had the value of Odds Ratio 4.75 which meant that pregnant women with high perceived vulnerability had 4.75 times more possibilities in conducting HIV/ AIDS tests than those with low perceived vulnerability. This analysis result indicated that there was 
Journal of Health Promotion and Behavior (2017), 2(2): 112-123

https://doi.org/10.26911/thejhpb.2017.02.02.02

an influence of the perceived vulnerability on the conduct of HIV/AIDS tests and was statistically very significant ( $\mathrm{OR}=4.75 ; 95 \%$ $\mathrm{CI}=2.17$ to $10.71 ; \mathrm{p}<0.001)$.

The variable of perceived benefits had the value of Odds Ratio 4.37 which meant that pregnant women with high perceived benefits had 4.37 times more possibilities to conduct HIV/ AIDS tests than those with low perceived benefits. This analysis result indicated that there was an influence of the perceived benefits on the conduct of HIV/
AIDS tests and was statistically very significant $(\mathrm{OR}=4.37 ; 95 \% \mathrm{CI}=1.95$ to $9.82 ; \mathrm{p}<$ 0.001)

\section{Path Analysis}

The calculation result using path analysis to cognise the influence of family support, family income, information exposure, perceived seriousness, perceived obstacles, perceived vulnerability and perceived benefits in conducting HIV/AIDS test can be figured in Table 4.

Table 4. Path analysis of biopsychosocial determinants of pregnant women in conducting HIV/AIDS tests in Madiun

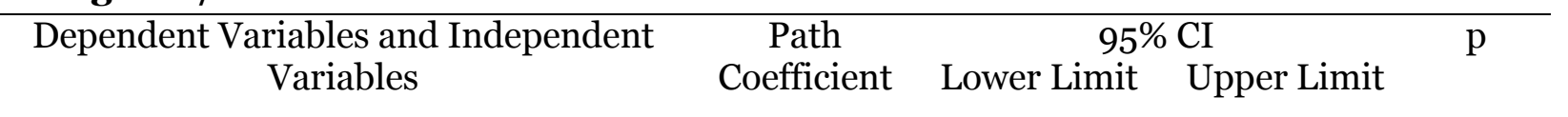

\begin{tabular}{lcccc}
\hline Direct Influence & & & & \\
HIV/AIDS Test $\leftarrow$ & & & & \\
Strong Family Support & 1.57 & 0.52 & 2.63 & 0.004 \\
High Perceived seriousness & 1.21 & 0.14 & 2.28 & 0.027 \\
High Perceived obstacles & -0.92 & -1.99 & 0.15 & 0.093 \\
High Perceived vulnerability & 1.12 & 0.12 & 2.13 & 0.028 \\
High Perceived benefits & 1.28 & 0.23 & 2.31 & 0.017 \\
Indirect Influence $\leftarrow$ & & & & \\
Perceived seriousness & & & & \\
High Information Exposure & 1.14 & 0.33 & 1.95 & 0.006 \\
Perceived obstacles & & & & \\
Family Income $\geq$ Rp. $1.509 .005,00$ & -0.73 & -1.51 & 0.05 & 0.067 \\
N observasi = 108 & & & & \\
Log likehood = -188.82 & & & & \\
AIC $=397.65$ & & & & \\
BIC $=424.47$ & & & & \\
\hline
\end{tabular}

The results using path analysis indicated that family support, perceived seriousness, perceived obstacles, perceived vulnerability and perceived benefits were all direct factors that influence the behaviour of pregnant women in conducting HIV/ AIDS tests. Whereas independent variables that influenced indirectly were information exposure to perceived seriousness and family income to perceived obstacles.

Pregnant women who had gotten strong family support in conducting HIV/ AIDS tests had log odds 2.63 points more probabilities in conducting the HIV/ AIDS tests than those who had gotten weak/low family support $(b=1.57 ; 95 \% \mathrm{CI}=0.52$ to 2.63; $\mathrm{p}=0.004$ ).

Pregnant women who had the perceptions that HIV infection was a serious matter had log odds 1.21 points more probabilities in conducting the HIV/AIDS tests than those who had perceptions that HIV infection was not a serious matter $(\mathrm{b}=1.21 ; 95 \% \mathrm{CI}=0.14$ to $2.28 ; \mathrm{p}=0.027$ ).

Pregnant women who had high perceived obstacles in conducting HIV/AIDS 
tests had the log odds 0.92 points less probabilities than those who had low perceived obstacles in conducting HIV/ AIDS tests $(b=-0.92 ; 95 \% \mathrm{CI}=-1.99$ to 0.15 ; $\mathrm{p}=$ 0.093).

Pregnant women who had the perceptions that they were susceptible to get HIV infected had log odds 1.12 points more probabilities in conducting HIV/AIDS tests than those who had perceptions that they were not susceptible to get HIV infected $(b=1.12 ; 95 \% \mathrm{CI}=0.12$ to $2.13 ; \mathrm{p}=0.028)$.

Pregnant women who had high perceived benefits in conducting HIV/ AIDS tests had log odds 1.28 points more possibilities in conducting HIV/ AIDS tests that those who had low perceived benefits in conducting HIV/ AIDS tests $(b=1.28$; 95\% $\mathrm{CI}=0.23$ to $2.31 ; \mathrm{p}=0.017$ )

Perceived seriousness were determined by information exposure. Pregnant women who had high information exposures in conducting HIV/ AIDS tests had 1.14 points more possibilities in conducting HIV/ AIDS tests than those who had not exposed to any information $(b=1.14 ; 95 \%$ $\mathrm{CI}=0.33$ to $1.95 ; \mathrm{p}=0.006$ ).

Perceived obstacles were determined by family income. Pregnant women who had family income $\geq$ Rp. 1.509.005,00 had $\log$ odds 0.73 points more possibilities in conducting HIV/ AIDS tests than those who had family income <Rp. 1509.005,00 (b=$0.73 ; 95 \% \mathrm{CI}=-1.51$ to $0.05 ; \mathrm{p}=0.067)$.

\section{DISCUSSION}

\section{Biopsychosocial Determinants of Pregnant Women's Behaviour in Conducting HIV/ AIDS Tests. \\ a. Proximate Determinants}

The analysis results indicated that there was a correlation between family support and behaviour in conducting HIV/ AIDS tests and was statistically significant, be- cause in facing health problems, each individual was in relations with the roles of other family members. Thus, it needed an approach hollistically. This is in accordance with the theory suggested by Prasetyawati (2011) which states that individual health problems are the components of the individual maintance systems. An individual is a part of a family and society which includes biomedical and psychological aspects, aspects of knowledge, attitude and behaviour, social aspect and environmental aspect.

The results of this study indicated that there was a correlation between perceived seriousness and the conduct of HIV/AIDS tests and was statistically significant. The more serious it is, the more deteriorating a disease is, the harder the efforts are to prevent it, which is conducting the HIV/AIDS test.

The theory of Health Belief Model (HBM) developed by Rosenstock (1994) states that perceived seriousness or severity of a disease causes an individual to acquire the attitude in putting any efforts for medications. Bakhtari et al (2012) state that an individual will take any actions to protect himself should he/she assumes that the individual's condition is in a serious state. This study supports a previous study conducted by Fazriah (2014) whose result indicated that the low perceived seriousness were influencial to the use of screening IVA. Pregnant women with high perceived seriousness in the disease of HIV/AIDS will tend to do the HIV/AIDS tests because they have understood that this disease is hazardous for the infants in their wombs.

The results of this study indicated that there was a correlation between perceived obstacles in conducting HIV/AIDS tests and was statistically significant. This means that the more an individual feels on how big the obstacle is in conducting the behavior, the smaller the success of conducting the 
Journal of Health Promotion and Behavior (2017), 2(2): 112-123

https://doi.org/10.26911/thejhpb.2017.02.02.02

behaviour. The theory of HBM developed by Rosenstock (1994) states that obstacles are potential negative consequences which may emerge when an individual takes some certain actions, including physical, psychological and financial demands.

HBM also states that everything that impedes will slow down an individual in changing some certain behaviour, either from the aspects of distance, costs or any other obstacles which come from an individual's husband or environment. The obstacles of pregnant women in conducting HIV/ AIDS tests may be the distance between their residences and health services, costs of examinations, or the lack of information in conducting HIV/ AIDS tests or not being allowed by their husbands.

The results of this study also support the previous study conducted by Purwaningsih (2010) which cognised the correlation between obstacles and behaviour in utilising VCT (Voluntary Counseling and Testing) in Community Health Centres in Dupak, and another by Budiman (2008) who states that there is a correlation between obstacles and behaviour to prevent IMSand HIV infections spread among prostitutes in District of Klaten. There is also another study by Faulina (2009) which indicates that there is a correlation between transgender sexual behaviour and the transmissions of HIV/ AIDS in Tarakan, Province of East Borneo with $\mathrm{p}=0.037$.

The results of this study indicated that there was a correlation between the individual perceived vulnerability and the behaviour in conducting HIV/AIDS tests and was statistically significant. This means that when an individual realises that he/she is susceptible to get infected, in this matter is HIV/AIDS, then the individual will do any efforts to prevent that by conducting the HIV/AIDS test. This result corresponds to the theory of HBM developed by Rosen- stock (1994) which states that an individual's assumption that he/ she is susceptible to get infected by any diseases will make the individual to manage a protection.

The theories that support a statement which says vulnerability makes an individual to behave are Karl and Cobb (1966) and Browning (2005). They state that an individual will believe that the actions the individual does are parts of his/ her health maintenance (well behavior). Every individual's behaviour is excercised because the individual feels that he/she is sick and will seek for helps and recovery for him/herself (symptom based/illness behavior). The vulnerability felt by pregnant women in conducting HIV/AIDS tests are part of the efforts to healing (sick role behavior). A theory from Skiner (1983) quoted by Notoadmodjo (2005) in his study, states that stimulants or stimuli will drive an individual to behave, and the individual will act to make any preventions and medications for the symptoms or diseases the individual feels. To do some actions, an individual has to feel susceptible to the diseases.

The results on bivariate analysis indicated that there was a correlation between perceived benefits which were felt in conducting HIV/ AIDS tests and was statistically very significant. This means that when an individual feels the benefits of behaviour to avoid getting infected any diseases, then there is no impacts in doing such behaviour. This result supports a previous study conducted by Faulina (2009) and Bock (2009) which states that there is a correlation between benefits and behaviour to prevent HIV/AIDS infection with $\mathrm{p}=$ o.004.

The theory of HBM developed by Rosenstock (1994) says that the higher the effectivity of the levels of beliefs in a strategy which is designed to reduce the threats 
to a disease, the more individual do the preventive actions on the individual's own intention, in this matter is conducting the HIV/ AIDS tests. According to Spiritia (2005), knowing the status of HIV earlier during pregnancy is very beneficial for the mother and baby. Therefore, HIV tests should be offered to pregnant women that have behaved at risk. However, the test should be done voluntarily, without pressures, and equipped with counsellings before and after the tests, and with informed consents.

\section{b. Contextual Determinants}

The results of this study indicated that there was an influence of information exposure in conducting HIV/AIDS test and was statistically significant. Pregnant women had gotten the information about HIV/ AIDS at the time of prenatal care by the health workers. The theory of HBM states that behaviour with an intention to avoid getting infected to any diseases or minimising health risks is exercised because there are clues or certain signs such as information, certain experiences on the diseases either obtained from the family, friends or environment.

The results of this study corresponds to the theory of Instinct by Mc. Dougall which says that behaviour is exercised because an individual has experienced changes from any experiences (Walgito, 2010). Besides, there is also a theory from Naido (2004) who says that behaviour is exercised because there is information. Another theory suggested by Snechandu B. Kars which says that an individual behaves because there is information.

This study corresponds to the one conducted by Chartika et al (2013) which states that information exposure of mass media such as newspapers, television, radio, leaflets and posters can influence the levels of an individual's knowledge in un- derstanding some things as those faced by narcotics injection users in Pontianak. Information accessibilities on HIV/AIDS will also influence the levels of narcotics injections users in understanding how to prevent HIV/AIDS. The more they are exposed to such information especially about HIV/ AIDS preventions, the higher their levels of knowledge which later will influence their attitude and behaviour. Furthermore, a study conducted by Lamarque (2013), in Fort Daupin, Madagaskar shows that the knowledge on various aspects of HIV/AIDS is the factor found by the researcher which can play a role in the decision making process to do the HIV test. A study conducted by Afifah (2011) also states that there is a correlation between information exposure and the behaviour of HIV/AIDS preventions for Senior High School and equal academic school students in Cilacap in 2011 with the value of $p=0,00$.

The results of statistical test indicated that there was a significant correlation between family income and the conduct of HIV/ AIDS tests. The results of path analysis indicated that the family income was an indirect influencial factor to perceived obstacles. The low family income would have high perceived obstacles in conducting HIV/ AIDS test. Whereas high family income would have low perceived obstacles in conducting HIV/AIDS test.

The results of this study corresponds to a previous study conducted by Tasa, Ratu Ludji and Paun (2016) which states that thereis a correlation between family income and the use of VCT. This is caused by other factors that influence each other. A theory by Oemiati et al (2011) says that the economic status that is increasing, makes the necessities to visit health services are increasing too. Societies within mid to upper economic status will be more exposed to information about HIV/AIDS than societies 
within mid to lower economic status. Based on the theory suggested by Gilarso (2008), family income is remuneration or rewards which are gained in returns of the donations given in production activities which come from own's efforts, working with other people and rewards from available options.

\section{REFERENCE}

Afifah FN (2011). Faktor-Faktor yang Berhubungan dengan Perilaku Pencegahan HIV/AIDS di Kalangan Remaja SMA dan Sederajat diKota Cilacap Tahun 2011. Tesis. Universitas Indonesia.

Bakthari AF, Nuri ZR, Suhebi L (2012). Effect of Education Based on Health Belief Model on Believe Promotion and Screening Behaviours of Breast Cancer among Women Reffered to Tabriz Health Centers. Medl J Tabriz Uni Medl Sci 33: 25-31. In Persian, "n.d. Diakses 7 Januari 2017.

Bock (2008). Factors Influencing The Uptake of Voluntary Counceling And Testing In Namibia. Netherlands; University Amsterdam.

Browning CJ, Thomas SA (2005). Behavioural Change An Evidence-Based HandBook For Social and Public Health. Sidney.

Budiman NA, Istiarti T, Hadi S (2008). Faktor Yang Berhubungan dengan Praktek WPS Jalanan dalam Upaya Pencegahan IMS dan HIV-AIDS di Sekitar Alun-Alun dan Candi Prambanan Kabupaten Klaten. Promkes Indonesia 3: 108.

Chartika W, Hermawan AD, Ridha A (2013). Hubungan antara Pengetahuan, Sikap, Akses Informasi HIV/ AIDS dan Dukungan Keluarga dengan Perilaku Pencegahan HIV/AIDS Pada Pengguna Napza Suntik di Kota Pontianak. JuManTik: 163-172.
Dinas Kesehatan Kota Madiun (2015). Profil Kesehatan Kota Madiun

Faulina R (2009). Perilaku Seks Waria Kaitannya dengan Penularan HIV-AIDS di Kota Tarakan Provinsi Kalimantan Timur. Semarang: Tesis, Universitas Diponegoro.

Gilarso T (2008). Pengantar Ilmu Ekonomi Mikro Edisi 5. Yogyakarta : Kanisius.

Kementrian Kesehatan RI Direktorat Jendral PP \& PL (2011). Rencana Aksi Kegiatan Pengendalian HIV-AIDS dan IMS Tahun 2010 - 2014. Jakarta

Lamarque KJ (2013). HIV Testing of Pregnant Women in Fort Daphin Region Of Madagascar. Tesis: Stellenbosh University.

Mulyanti S (2012). Faktor-Faktor yang Berkontribusi pada Perilaku Ibu Hamil Trimester 2 dan 3 dalam Pemeriksaan HIV di Empat Puskesmas Kota Pontianak Tahun 2012. Skripsi : Fakultas Kesehatan Masyarakat, Program Kebidanan Komunitas, Universitas Indonesia.

Murti B (2016). Riset Epidemiologi. Surakarta : UNS Press

Naido J, Wills J (2004). Health Promotion. New York: Bailliere Tindal Royal College of Nursing.

Notoatmodjo S (2010). Promosi Kesehatan dan Ilmu Perilaku. Jakarta : Rineka Cipta.

Oemiati R, Rahajeng E, Kristanto AY (2007). Prevalensi tumor dan beberapa faktor yang mempengaruhinya di Indonesia. Buletin Penelitian Kesehatan 39 (4): 190-204.

Prasetyawati AE (2011). Ilmu Kesehatan Masyarakat untuk kebidanan holistik (integrasi community oriented ke family oriented). Yogyakarta: Nuha Medika. 
Spiritia (2009). Dasar AIDS. http://spiritia. or.id/art/pdf/a1001.pdf. Diakses tanggal 8 November 2016.

Tasa Y, RatuLudji, Ina D, Paun, Rafael (2016). Pemanfaatan Voluntary Counselling and Testing Oleh Ibu Rumah Tangga Terinfeksi Human Immunodeficiency Virus. Jurnal Kesehatan Masyarakat. KEMAS 11 (2)

Towsen C (2008). HIV Research. London: The Kaiser Daily HIV-AIDS

UNAIDS (2015). UNAIDS Report On The Global AIDS Epidemic 2015. Global Report. UNAIDS

Undang - Undang No. 52 (2009). Undang Undang Republik Indonesia Nomor 52 tahun 2009 tentang perkembangan kependudukan dan pembangunan keluarga.
Walgito B (2010). Pengantar Psikologi Umum. Yogyakarta: Ani Offset.

World Health Oganization (2013). UNAIDS and UNODC. Policy Brief: Reduction of HIV Transmission In Prions. Geneva: WHO.

Wulansari A. (2014). Faktor - Faktor yang Berhubungan dengan Niat Ibu Hamil untuk Memanfaatkan Layanan VCT (Voluntary Counseling and Testing) di Wilayah Kerja Puskesmas Ciputat Kota Tangerang Provinsi Banten Tahun 2014. Skripsi: Fakultas Kedokteran dan Ilmu Kesehatan Universitas Islam Negeri Syarif Hidayatullah Jakarta. 